\title{
Kinetics of in situ degradation of barley (Hordeum vulgare L.) at different cut ages
}

\begin{abstract}
The objective of this work was to evaluate the potential and effective in situ degradability of dry matter (DM), crude protein (CP), neutral detergent fiber (NDF) and acid detergent fiber of barley ( Hordeum vulgare L.) in Cutting ages: 130, 150 and 170 days. Bovine males of the Brown swiss breed, fistulated in the rumen, with ages of 3 years, and average weight of $435 \mathrm{~kg}$ were used. The experiment was carried out in completely randomized block design ( 3 animals), with a factorial arrangement of $3 \times 6$ (cutting ages and incubation times). The barley according to the cut ages were weighed in nylon sacks and incubated all at once and removed at the times of $0,6,12,24,48$ and 72 hours, after incubation. Cutting age, incubation time and interactions between age and incubation time influenced the rumen degradability of DM, CP, NDF and FDA, except for the CP that there was no significant interaction between age and time. The analysis of variance of the regression did not reveal an effect of the cutoff age on the potential or effective degradability of the MS in the pass rates of 2,5 and $8 \%$ /hour. The constant degradation rates "c" of the $\mathrm{CP}(3.00,6.33$, $6.33 \% / \mathrm{h}$, respectively), NDF $(2.80,2.77,3.39 \% / \mathrm{h})$ and $\operatorname{ADF}(3.01,3.02,3.35 \% / \mathrm{h})$ were low. The potential degradability's of the DM $(86.71,90.27,82.83 \%), \mathrm{CP}(89.48$, $77.69,82.15 \%)$, NDF $(85.21,72.81,81.18 \%)$ and $\operatorname{ADF}(86.41,70.33,80.76 \%)$ were high, with models of quadratic type regression; as well as the effective degradability of the PC at the passage rate of $5 \% / \mathrm{h}(66.04,66.21,69.54 \%)$, NDF $(56.09,51.10$, $58.60 \%)$ and $\operatorname{ADF}(58.26,50.23,54.07 \%)$. Due to the higher soluble fractions and high effective degradability's of CP in the three cut ages evaluated, this species can be classified as having a good nutritional quality
\end{abstract}

Keywords: potential degradability, effective degradability, incubation time, rate of passage
Volume 7 Issue 6 - 2018

\author{
José L Contreras P,' José Ochoa F,' Rodrigo \\ Huamán J, ${ }^{2}$ Alfonso G Cordero $\mathrm{F}^{3}$ James \\ Curasma C,' Yola V Ramos E,' Rita Gutiérrez \\ C \\ 'Laboratory of animal nutrition and food evaluation (LUNEA): \\ E.P.Zootechnics. National University of Huancavelica, Perú \\ ${ }^{2}$ Edaphology Laboratory of the National University of \\ Huancavelica, Perú \\ ${ }^{3}$ Teaching in Animal Production mention of Graduate School of \\ the Faculty of Engineering, UNH, Huancavelica Perú
}

\author{
Correspondence: Contreras Paco Jose L,Academic \\ Department of Zootechnics, National University of \\ Huancavelica, Ave university s/n Paturpampa postal code \\ 0900 I,Perú,Tel +5 I 948I33886, \\ Email jose.contriras@unh.edu.pe
}

Received: August 16, 2018 | Published: December 14, 2018

\section{Introduction}

The climatic conditions of the highlands of Peru differentiate two well defined periods, a short period of rain, with abundant good quality pasture and a period with a decrease in temperature, reduction of the photoperiod and absence of rains that give rise to quantitative and qualitative deficits in the production of the pastures, preferably in the dry and cold season (between May and October) of each year. In this period the pastures do not provide all the nutrients, this means that the animals do not manage to cover their nutritional requirements, playing an important role in feeding the livestock. ${ }^{1}$ Animal feeding in the highlands of Peru is based mainly on the use of forages, as well as harvest residues. In many cases, due to the low availability and low nutritive value of the pastures, there is an imbalance between the nutrients consumed and the physiological demand of the animal, which limits the productivity of the animal production system. The "In situ" degradability technique is a way to indirectly evaluate the (potential - effective) degradability and digestibility of food, being one of the measurements more coincident with reality, allowing us to study the dynamics of food transformation in the rumen. ${ }^{2}$ Harvesting times, incubation times of barley (Hordeum vulgare L.), and determination of neutral detergent fiber (NDF), acid detergent fiber (ADF), dry matter $(\mathrm{DM})$ and crude protein $(\mathrm{CP})$, are indicators for the determination of forage quality. ${ }^{3}$ Taking into account the aforementioned aspects, the present research work was proposed, with the following objective: kinetics of in situ degradation of barley (Hordeum vulgare L.) at different cutting ages.

\section{Methods}

\section{Location of the experimental area}

The Center for Research and Development sudamericanos camelids Lachocc-Tambocucho of the National University of Huancavelica (UNH), where crops were installed barley (Hordeum vulgare L.) variety San Cristobal -411 at an altitude of 4350 masl, located in the district, province and Huancavelica-Peru region, in October 2016 , the objective of the study was to estimate the in situ degradability parameters of the DM, CP, NDF and ADF, in three cutting ages (130, 150 and 170 days) of the forage barley crop. 5 plots were established by age, with an area of $16 \mathrm{~m} 2$ by plot, of each of these plots according to the established age, all green experimental material was cut and then approximately $500 \mathrm{~g}$ were removed to constitute a composite sample of $2,500 \mathrm{~kg}$. Of this amount, $500 \mathrm{~g}$ of sample per treatment were used for the degradability tests. The in situ degradability study was carried out in the facilities of the Professional Academic School of Zootechnics (EAPZ) of the Faculty of Engineering Sciences belonging to the UNH; the altitude above sea level is 3704 meters above sea level, the average annual temperature of $9.0^{\circ} \mathrm{C}$ and the average annual rainfall of $784 \mathrm{~mm}$. Three bovine males of the Brown Swiss breed, aged 3 years and weights varying between 420 and $450 \mathrm{~kg}$, were used in the rumen, animals in healthy, unneutered and deformed conditions. The animals remained confined throughout the experimental period, in berries made of wooden poles, covered with plastic and with a concrete floor. Each pen had a feeder and drinker with a capacity of 100 liters of water. During the pre (10 days) and 
experimental period the animals were fed with green barley and oats hay, supplied twice a day ( 8 and 17 hours). The animals had free access to water and mineral salt.

\section{Degradability in situ}

The DM, CP, NDF and FDA degradability of the barley at the cutoff ages of 130, 150 and 170 days were determined by incubation of $5 \mathrm{~g}$ of dry sample in air, in bags of nylon, size $5 \times 10 \mathrm{~cm}$ and $50 \mu \mathrm{m}$ in dimension ${ }^{4}$ identified and sealed each one of them. The bags were incubated during $0,6,12,24,48$ and 72 hours $^{5}$ in the ventral part of the rumen of the animals. The number of samples used for 3 cutting ages of barley, 3animals, 2repetitions/animal and 6 incubation times were: $3 \times 3 \times 2 \times 6=108$ samples. The bag corresponding to time 0 hours were not incubated, but they were immersed in water at $39^{\circ} \mathrm{C}$ for 15 minutes and dried in a forced ventilation oven at $60^{\circ} \mathrm{C}$ for 24 hours. The bags were placed at the same time and removed according to the aforementioned incubation times. Subsequently, they were washed several times until the water was clear $(5 \mathrm{~L} / \mathrm{bag})$. They were dried in a forced ventilation oven at $60^{\circ} \mathrm{C}$ for 24 hours, finally being weighed and kept in plastic containers until the analyzes were carried out. Losses of DM, CP, NDF and ADF were estimated, before and after washing, by differences in bag weights. The disappearance of the DM, CP, NDF and ADF for each incubation time were estimated as disappearance of the $\mathrm{DM}, \mathrm{CP}, \mathrm{NDF}$ and $\mathrm{ADF} \%=[(\mathrm{DM}$ or $\mathrm{CP}$ or $\mathrm{NDF}$ or initial ADF - DM or CP or NDF or ADF final)/(DM or CP or NDF or initial ADF)] $x$ 100. The degradation parameters of the DM, $\mathrm{CP}, \mathrm{NDF}$ and ADF were obtained by fitting the data to the equation described by Orskov et al., ${ }^{6}$

$$
\operatorname{Deg} \$(x)=a+b x(1-\exp (-c x t)))
$$

Where: Deg ( $t)$, represents the amount of degradation or disappearance of the nutrient (DM, or CP, or NDF or ADF) (\%) of the food at time (t) (\%); a, is the fraction of the water-soluble food at time zero (initial degradation, $\%$ ); b, represents the potentially degradable fraction and expresses the fraction that was degraded in time ( $\mathrm{t}$ ) (fraction degraded by microorganisms, maximum degradation, $\%$ ); $\mathrm{c}$, is the rate of degradation in which fraction $\mathrm{b}$ will be degraded every hour ( $\% /$ hour $) ; t$, is the incubation time in the rumen (hours); exp, base of natural logarithms; $a+b \leq 100$. The nonlinear parameters $\mathrm{a}, \mathrm{b}$ and $\mathrm{c}$ were estimated with the Microsoft Excel Solver application. The effective degradability, which corresponds to the potential degradation $(\mathrm{a}+\mathrm{b})$ adjusted by the passage rate $(\mathrm{k})$, was estimated the effective degradability of the DM (DEDM), CP(DECP), NDF (DENFD) and ADF (DEADF)) in the rumen by the equation of Orskov et al., ${ }^{6}$ :

$$
D e=a+[(b x c) /(c+k)]
$$

Where: $k$, is the estimated rate of passage of the particles in the rumen and the other parameters were described in the previous equation.

The DEDM, DECP, DENDF and DEADF were estimated for age of cut, taking into account the rates of passage of solids in the rumen of $2 \% / \mathrm{h}, 5 \% / \mathrm{h}$ and $8 \% / \mathrm{h}$, corresponding to maintenance and moderate productive levels and high. ${ }^{7}$

\section{Experimental design and statistical analysis}

The experiment was carried out using the completely random block design ( 3 animals), with a factorial arrangement of $3 \times 6$ (cut- off times $\mathrm{x}$ incubation times), according to the following statistical model:

$$
\text { And } i j k=\mu+E i+I j+(E x I) i j+e i j k D
$$

where: Y ijk, Refers to the response variable ( parameters of in situ degradation ); $\mu$, General average; EI, Effect of cutting age of barley $\mathrm{i}$, varying I, 1, 2, 3; I j, Effect of ruminal incubation times $\mathrm{j}$, varying $\mathrm{j}, 1,2,3,4,5,6$; (E x I) ij, Effect of the interaction between factors $\mathrm{E}$ and I; y e ijk, Normally and independently distributed random variable with a mean $\varnothing$ and variance $\sigma \mathrm{e}^{2}$. The GLM procedure of the $\mathrm{SAS}^{8}$ was used to analyze the data. The differences between means were estimated by the Turkey test, with significance level of $\mathrm{P}<0.05$ probability. Additionally, the variance analysis of the regression was performed for the degradability parameters, according to the cut ages of the barley.

\section{Results}

\section{Degradability of barley nutrients at different cut ages}

The summary of the analysis of variance of the degradability variables of the DM, CP, NDF and ADF is found in Table 1. The effect of the animal was not significant for the DM and CP, which differs from the results reported by Villela et al., ${ }^{9}$ \& Rogério da Silva, ${ }^{10}$ who found significant differences $(\mathrm{P}<0.01)$ between animals for CP degradability. For the NDF and ADF there was significant influence $(\mathrm{P}<0.01)$ of the animal. There was an effect of cut age on the degradability of DM, NDF, ADF $(\mathrm{P}<0.001)$ and $\mathrm{CP}(\mathrm{P}<0.01)$, indicating that for these variables, barley at different cutting ages has different behaviors in the rumen. As expected, the incubation time factor had a significant effect $(\mathrm{P}<0.001)$ for all ages of barley cut on DM, CP, NDF and ADF degradability's. There was an effect of the interaction of cut age and incubation time for $\mathrm{DM}(\mathrm{P}<0.05)$, NDF and ADF $(\mathrm{P}<0.01)$, and without interaction between the factors for $\mathrm{PC}(\mathrm{P}>0.05)$. The DM degradability increased $(\mathrm{P}<0.001)$ as a function of the incubation time for the three cut ages of the barley the average degradability's reached higher values, practically at 72 hours of incubation (Table 2). There were no significant differences $(\mathrm{P}>0.05)$ in the DM degradability in the three cut-off ages at 0,6 and 12 hours of incubation, with a decrease $(\mathrm{P}<0.01)$ in the DM degradability of the 130 at 150 , then increase to 170 cut days, at 24 , 48 and 72 hours of incubation. $\mathrm{CP}$ degradability increased $(\mathrm{P}<0.001)$ as a function of the incubation time for the three cut-off ages; there was a large soluble fraction (time 0 ) for $\mathrm{CP}$, ranging between $51.48 \%$ and $59.32 \%$. In all cut-off ages the cell wall (NDF) was degraded to a greater degree at 72 hours of incubation, with degradability's that varied $(\mathrm{P}<0.001)$ between $69.06 \%$ and $80.59 \%$. The degradability of the lignocelluloses fraction (ADF) in the three cut-off ages increased $(\mathrm{P}<0.001)$ as a function of the incubation time, degrading between $66.77 \%$ and $80.02 \%$, after 72 hours of incubation.

\section{Degradability in situ of the dry matter (DM) of the barley in different ages of cut}

The estimates of the parameters of the soluble fraction or initial degradability "a", slowly degradable or maximum degradability "b" and constant rate of degradation of the fraction $\mathrm{b}$ " $\mathrm{c}$ " of the equations adjusted for the potential degradability's of the MS (DPDM) and effective (DEDM) of the barley at different cut ages, are shown in Table 3. The analysis of variance did not reveal significant differences $(\mathrm{P}>0.05)$ for "a", DPDM and DEDM at the pass rates of $2 \% / \mathrm{h}, 5 \% / \mathrm{h}$ 
and $8 \% / \mathrm{h}$ of the $\mathrm{DM}$ of the barley. Also, the analysis of variance of the regression did not reveal the effect of barley cut-off ages on any parameter of DM degradability. The DPDM in the three cut ages of the barley were similar, with an average of $86.60 \%$. However, the highest percentage of the degradability was constituted by the slowly

Table I Summary of the analysis of variance of the rumen degradability of dry matter (DM), crude protein (PC), neutral detergent fiber (NDF) and acid detergent fiber (ADF) of barley at different cut ages

\begin{tabular}{|c|c|c|c|c|c|}
\hline \multirow[t]{2}{*}{ Sources of variation } & \multirow[t]{2}{*}{ GL } & \multicolumn{4}{|c|}{ Average squares } \\
\hline & & DM (\%) & CP (\% DM) & NDF (\% DM) & ADF (\% DM) \\
\hline Animal & 2 & $16,146^{\mathrm{ns}}$ & $9,369^{\text {ns }}$ & $34,598 * *$ & $40,137 * *$ \\
\hline Cutting age (E) & 2 & $245,154 * * *$ & $59,068 * *$ & $270,284 * * *$ & $332,649 * * *$ \\
\hline Incubation time $(\mathrm{T})$ & 5 & $3236,698 * * *$ & $816,322 * * *$ & $1590,432 * * *$ & $1702,535^{* * *}$ \\
\hline Interaction $\mathrm{E} \times \mathrm{T}$ & 10 & $27,454^{*}$ & $14.405^{\mathrm{ns}}$ & $16,142 * *$ & $22,522^{* *}$ \\
\hline Error & 3.4 & 12,194 & 9.308 & 5.071 & 7.141 \\
\hline Total & 53 & & & & \\
\hline CV (\%) & & 8.83 & 4.45 & 3.91 & 4.73 \\
\hline
\end{tabular}

ns, ***; *** Not significant and significant when $\mathrm{P}<0.05, \mathrm{P}<0.0 \mathrm{I}$ and $\mathrm{P}<0.00 \mathrm{I}$, respectively

Table 2 Ruminal degradation percentage of dry matter, crude protein, neutral detergent fiber and acid detergent fiber of barley, depending at different cutting and incubation ages (hours)

\begin{tabular}{|c|c|c|c|c|c|c|}
\hline \multirow[t]{3}{*}{ Ages of court (days) } & \multicolumn{6}{|c|}{ Dry material } \\
\hline & \multicolumn{6}{|c|}{ Incubation time (hours) } \\
\hline & 0 & 6 & 12 & 24 & 48 & 72 \\
\hline 130 & 15.69 & 26.01 & 36.89 & 42.27 & 58.5 & 73.13 \\
\hline 150 & 15.12 & 24.35 & 30.22 & 34.15 & 48.08 & 59.88 \\
\hline \multirow[t]{2}{*}{170} & 16.72 & 27.95 & 31.28 & 43.54 & 59.44 & 68.34 \\
\hline & \multicolumn{6}{|c|}{ Crude protein } \\
\hline 130 & 53.37 & 59.19 & 64.59 & 70.22 & 76.51 & 83.56 \\
\hline 150 & 51.48 & 60.27 & 67.48 & 69.63 & 75.78 & 78.12 \\
\hline \multirow[t]{2}{*}{170} & 59.32 & 65.36 & 68.79 & 73.12 & 76.95 & 79.95 \\
\hline & \multicolumn{6}{|c|}{ Neutral detergent fiber } \\
\hline 130 & 38.27 & 47.4 & 55.35 & 59.52 & 71.24 & 80.59 \\
\hline 150 & 36.78 & 46.41 & 50.94 & 53.02 & 63.21 & 69.06 \\
\hline \multirow[t]{2}{*}{170} & 43.12 & 52.69 & 55.1 & 63.04 & 73 & 77.35 \\
\hline & \multicolumn{6}{|c|}{ Acid detergent fiber } \\
\hline 130 & 40.73 & 48.54 & 57.27 & 62.7 & 73.68 & 82.02 \\
\hline 150 & 36.83 & 45.38 & 49.16 & 52.77 & 62.43 & 66.77 \\
\hline 170 & 35.56 & 48.61 & 49.7 & 59.09 & 70.13 & 75.96 \\
\hline
\end{tabular}

Table 3 Averages of the parameters of degradability of the dry matter of the barley in different cutting ages

\begin{tabular}{|c|c|c|c|c|c|c|c|}
\hline \multirow{2}{*}{$\begin{array}{l}\text { Cutting age } \\
\text { (days) }\end{array}$} & \multicolumn{2}{|c|}{ Parameters } & \multirow[b]{2}{*}{ c(\%/h) } & \multirow{2}{*}{$\begin{array}{l}\text { DPDM (\%) } \\
\mathbf{a + b}\end{array}$} & \multicolumn{2}{|c|}{ DEDM (\%) } & \multirow[b]{2}{*}{$8 \% / h$} \\
\hline & $a(\%)$ & $\mathbf{b}(\%)$ & & & $2 \% / h$ & $5 \% / h$ & \\
\hline 130 & $17.60^{\mathrm{a}}$ & $69.1 I^{a b}$ & $2.00^{\mathrm{ab}}$ & $86.7 I^{a}$ & $54.19^{a}$ & $39.06^{a}$ & $32.78^{a}$ \\
\hline 150 & $17.57^{\mathrm{a}}$ & $72.70^{\mathrm{a}}$ & $1.67^{b}$ & $90.27^{\mathrm{a}}$ & $51.01^{\mathrm{a}}$ & $36.54^{\mathrm{a}}$ & $30.88^{a}$ \\
\hline 170 & $17.60^{\mathrm{a}}$ & $65.23^{b}$ & $2.33^{\mathrm{a}}$ & $82.83^{a}$ & $51.27^{\mathrm{a}}$ & $37.35^{\mathrm{a}}$ & $31.6 \mathrm{I}^{\mathrm{a}}$ \\
\hline
\end{tabular}

In situ degradability of crude protein (CP) of barley at (DPCP) and of the effective degradability's (DECP) for the rates of different cut ages passages of 2,5 and $8 \% / h$ of the barley in different ages of cut. The parameters "a", "b", "c", DPCP and DECP for the passage rates of 2, 5 and $8 \% /$ h were influenced $(\mathrm{P}<0.05)$ by the cut age of the barley. After

Table 4 shows the values of the parameters "a", "b", "c" of the equations adjusted for the potential degradability of the crude protein 
relation to the cuts made at 130 and 150 days (53.56\% and 51.97). \%), which do not differ from each other ( $\mathrm{P}>0.05)$. By means of the analysis of variance of regression it was verified that fraction "a" presented a quadratic response (Table 4); being attributed a decrease of $3.32 \%$ and an increase of $0.012 \%$ of the fraction "a" of the CP for each unit of age considered. The magnitude of the slowly degradable protein fraction "b" is a function of the time that the food remains subjected to the enzymatic activity of the rumen microorganisms. ${ }^{11}$ The DPCP between cut ages were different $(\mathrm{P}<0.05)$, however, the lowest percentage of degradability was constituted by fraction "b". At the age of 130 days, fraction " $b$ " of the $\mathrm{CP}$ was higher $(\mathrm{P}<0.05)$ than at 150 and 170 days of cut, which did not differ from each other. By the analysis of variance of the regression the fraction "b" of the CP presented a linear and quadratic trend. The DECP is an estimate of the total nitrogen captured and used by the rumen microorganisms for protein synthesis and growth ${ }^{1}$. Forage protein is susceptible to rapid degradation in the rumen especially that of green forages in which up to $73 \%$ is degraded ${ }^{5}$. At the age of 130 and 150 days of barley cut no significant differences were observed $(\mathrm{P}>0.05)$ in the DECP for the pass rates of $5 \% / \mathrm{h}$ and $8 \% / \mathrm{h}$, however there was superiority in the DECP of the barley cut at 130 days in relation to barley evaluated at 150 days of growth $(73.38 \%$ and $71.33 \%)$ at the passage rate of $2 \% / \mathrm{h}$. At this rate of passage there was similarity in the DECP between cut-off ages at 130 and 170 days. The analysis of variance of the regression established for the DECP in the rates of passages of $2 \% / \mathrm{h}, 5 \% / \mathrm{h}$ and $8 \% / \mathrm{h}$ responses of the quadratic type (Table 4). Regarding the DPCP $(a+b)$, the decrease experienced at the highest rate of passage $(\mathrm{k}=8 \% / \mathrm{h})$ corresponded $29.88 \%, 18.56 \%$ and $18.88 \%$ at the ages of 130,150 and 170 cut days, respectively. Barley at the age of 130 days cut with a DPCP depressant effect of $29.88 \%$, associated with the highest proportion of the insoluble fraction "b" of PC $(35.92 \%)$ and lower degradation rate $(3.00 \% / \mathrm{h})$ needed more time in the rumen to be well degraded. In contrast, barley at the ages of 150 and 170 cut days with decreases of the DPCP of $18.56 \%$ and $18.88 \%$ at the passage rate of $8 \% / \mathrm{h}$, fractions of "b" of $25.73 \%$ and $22.51 \%$ and rates Degradation constants of $6.33 \% / \mathrm{h}$ and $5.33 \% / \mathrm{h}$ allowed barley at those ages to stay a shorter time in the rumen. In addition, it can be asserted by the high values of the DECP, that almost all the available protein in the evaluated species was degraded in the rumen, being available for the microbial growth, together with the energetic fraction of the forages.

Table 4 Means and regression equations of the degradability parameters of the crude protein of the barley in different cutting ages

\begin{tabular}{|c|c|c|c|c|}
\hline \multirow[t]{2}{*}{ Parameters of degradation } & \multicolumn{3}{|c|}{ Cutting ages (days) } & \multirow[t]{2}{*}{ Regression equations and coefficients of determination (\%) } \\
\hline & 130 & 150 & 170 & \\
\hline $\mathrm{a}(\%)$ & $53.56^{b}$ & $51.97^{b}$ & $59.64^{\mathrm{a}}$ & $Y=289.604-3.325 * * * E+0.01 I 58^{* * *} E^{2}\left(R^{2}=67.7 I\right)$ \\
\hline b (\%) & $35.92^{\mathrm{a}}$ & $25.73^{b}$ & $22.5 I^{b}$ & $Y=271.861-2.9465 * * 0.0087 * * E+E^{2}\left(R^{2}=63.99\right)$ \\
\hline$c(\% / h)$ & $3.00^{\mathrm{b}}$ & $6.33^{\mathrm{a}}$ & $5.33^{\mathrm{a}}$ & $Y=-\mid 24.2917+1.683 * * E-0.0054 * E^{2}\left(R^{2}=25.48\right)$ \\
\hline DPCP (\%) & $89.48^{\mathrm{a}}$ & $77.69^{c}$ & $82.15^{b}$ & $\mathrm{Y}=561.837-6,272^{* * *} \mathrm{E}+0.0202^{* * *} \mathrm{E}^{2}\left(\mathrm{R}^{2}=55.20\right)$ \\
\hline DECP $2 \% / h$ & $73.38^{\text {th }}$ & $71.33^{\mathrm{b}}$ & $74.15^{\mathrm{a}}$ & $\mathrm{Y}=205.333-1,806^{* * *} \mathrm{E}+0.006 \mathrm{I}^{* * *} \mathrm{E}^{2}\left(\mathrm{R}^{2}=37.12\right)$ \\
\hline DECP 5\%/h & $66.04^{b}$ & $66.21^{b}$ & $69.54^{\mathrm{a}}$ & $Y=|4| .772-1.095 * E+0.00394 * * E^{2}\left(R^{2}=40.09\right)$ \\
\hline DECP $8 \% / h$ & $62.74^{\mathrm{b}}$ & $63.27^{\mathrm{b}}$ & $67.27^{\mathrm{a}}$ & $Y=\mid 43.773-1.187^{* *} E+0.0043 * * E^{2}\left(R^{2}=54.25\right)$ \\
\hline
\end{tabular}

Means with the same letter within a row do not differ significantly from each other, by the Tukey test at $5 \%$ probability.

A, soluble fraction (initial degradability); b, potentially degradable fraction (maximum degradability); , rate of degradation of fraction b; DPCP, maximum potential degradability of the CP;DECP $2 \% / \mathrm{h}$, effective rumen degradability of CP with passage rate of $2 \% /$ hour; DECP $5 \% / \mathrm{h}$, effective rumen degradability of the CP with passage rate of $5 \%$ / hour; DECP $8 \% / \mathrm{h}$, effective ruminal degradability of the CP with passage rate of $8 \% /$ hour of the barley at different cutting ages, $* ; * * ; * * *$ Significant when $P<0.05, P<0.01$ and $P<0.00$ I, respectively.

\section{In situ degradation of the neutral detergent fiber (NDF) of barley at different cutting ages}

The DPNDF at the age of 130 days resulted in 12.40 and 4.03 percentage points above the values obtained at 150 and 170 days, respectively, with incomplete digestion (I) of $14.79 \%, 27.19 \%$ and $18.82 \%$ for the three ages of cut studied. This shows that the cell wall of the barley obtained at 130 and 170 days of age was less fibrous compared to that observed at 150 days of cutting, favoring the conditions to the microbial attack and, consequently, increasing the potential degradability. The analysis of variance of the regression showed a quadratic effect $(\mathrm{P}<0.001)$ in the DPNDF as a function of the cut age (Table 5). The values of the DENDF, based on the cutoff ages, can be found in Table 5. It can be seen that the DEFDNs decreased to 150 days of cut in the pass rates of $2 \% / \mathrm{h}, 5 \% / \mathrm{h}$ and $8 \% / \mathrm{h}$, as a consequence of the greater maturity of the forage, which confers higher cell wall content. However, the DENDFs increased at the age of 170 days in relation to the ages of 130 and 150 days of cutting, establishing a second grade model for each of the passages rates evaluated. Taking into account that the degree of digestion of the NDF is highly dependent on the time of permanence of the food in the rumen or its speed of passage (k) (effective degradability). The DENDFs present minimum reductions of 66.28 to $51.55 \%, 58.66$ to $47.73 \%$ and 66.86 to $54.76 \%$ for the cutoff ages of 130,150 and 170 days, respectively, when the pass rates go from 2 to $8 \% / h$. These results indicate that the degradability and the energy value of the fiber were reduced by $14.73,10.93$ and 12.10 percentage points for animals of high level of production and consumption (dairy cows in early lactation, fattening calves), where the digestive transit is faster ${ }^{12}$ Fact that has not occurred in the present experiment. Well, taking into account the DPNDF $(a+b)$ and $k=8 \% / h$ the decrease in the degradability was $39.50 \%$, and that associated with the potentially degradable fraction "b" $(45.44 \%)$ and the degradation rate "c " $(2.80 \% / h)$, it was necessary a longer time to be degraded (slow degradability) the cell wall of the barley at the age of 130 days. The depressant effect of the passage rate $(8 \% / \mathrm{h})$ in the DENDF of the barley at 150 and 170 days were $34.45 \%$ and $32.54 \%$, respectively. 
Table 5 Means and regression equations of the degradability parameters of neutral detergent fiber of barley in different cutting ages.

\begin{tabular}{|c|c|c|c|c|}
\hline \multirow[t]{2}{*}{ Parameters of degradation } & \multicolumn{3}{|c|}{ Cutting ages (days) } & \multirow[t]{2}{*}{ Regression equations and coefficients of determination (\%) } \\
\hline & 130 & 150 & 170 & \\
\hline$a(\%)$ & $39.76^{\mathrm{b}}$ & $38.96^{c}$ & $44.03^{\mathrm{a}}$ & $\mathrm{Y}=188.250-2.097 * * * \mathrm{E}+0.0073 * * * \mathrm{E}^{2}\left(\mathrm{R}^{2}=84.16\right)$ \\
\hline $\mathrm{b}(\%)$ & $45.44^{\mathrm{a}}$ & $33.85^{b}$ & $37.15^{\mathrm{b}}$ & $\mathrm{Y}=484.012-5.795 * * * E+0.019 * * * \mathrm{E}^{2}\left(\mathrm{R}^{2}=64.7 \mathrm{I}\right)$ \\
\hline$c(\% / h)$ & $2.80^{\mathrm{b}}$ & $2.77^{\mathrm{b}}$ & $3.39^{a}$ & $Y=18.573-0.225 * E+0.00080 * E^{2}\left(R^{2}=27.82\right)$ \\
\hline DPNDF (\%) & $85.21^{\mathrm{a}}$ & $72.8 I^{c}$ & $81.18^{b}$ & $\mathrm{Y}=672.053-7.889 * * * \mathrm{E}+0.026 * * * \mathrm{E}^{2}\left(\mathrm{R}^{2}=65.18\right)$ \\
\hline DENDF $2 \% / \mathrm{h}$ & $66.28^{a}$ & $58.66^{\mathrm{b}}$ & $66.86^{\mathrm{a}}$ & $Y=50 I .3120-5.916 * * * E+0.0198 E^{2}\left(R^{2}=79.8 I\right)$ \\
\hline DENDF $5 \% / \mathrm{h}$ & $56.09^{\mathrm{b}}$ & $51.10^{c}$ & $58.60^{\mathrm{a}}$ & $Y=393.1279-0.0156 E+4.623 * * * E^{2}\left(R^{2}=84.39\right)$ \\
\hline DENDF $8 \% / h$ & $51.55^{\mathrm{b}}$ & $47.73^{c}$ & $54.76^{\mathrm{a}}$ & $\mathrm{Y}=340.583-3.985 * * * E+0.0136 * * * E^{2}\left(\mathrm{R}^{2}=86.04\right)$ \\
\hline
\end{tabular}

Means with the same letter within a row do not differ significantly from each other, by the Turkey test at $5 \%$ probability.

A, soluble fraction (initial degradability); b, potentially degradable fraction (maximum degradability); c, rate of degradation of fraction b; DPNDF, maximum potential degradability of the NDF; DENDF $2 \% / \mathrm{h}$, effective ruminal degradability of the NDF with passage rate of $2 \% / \mathrm{hour}$; DENDF $5 \% / \mathrm{h}$, effective ruminal degradability of the NDF with passage rate of $5 \% /$ hour; DENDF $8 \% / h$, effective ruminal degradability of the NDF with passage rate of $8 \% /$ hour of barley at different cutting ages.

*; **; *** Significant when $\mathrm{P}<0.05, \mathrm{P}<0.0 \mathrm{I}$ and $\mathrm{P}<0.00 \mathrm{I}$, respectively.

\section{In situ degradability of the acid detergent fiber} (ADF) of barley at different cutting ages

Table 6 shows the values of the estimates of the parameters "a", "b" and "c" of the equations adjusted for the potential degradability of the lignocelluloses fraction (ADF) of the barley in the three cutting ages. The values of the initial degradability "a" were relatively high for the ADF, there being a decrease as the cut age increases (Table 6). However, the analysis of variance revealed a quadratic response. The DPADF in the three cut-off ages showed significant differences $(\mathrm{P}<0.05)$, the highest value corresponding to the age of 130 cutting days, followed by the 150-day age and increased to 170 days. The DPADF was relatively constituted by a greater percentage of the insoluble part "b", but potentially degradable by the microorganisms of the rumen. The values of the DEADF, according to the ages of cut and rates of passages are found in Table 6 . It can be seen that the values decreased according to the increase in the age of cut, except for the age of 170 days, whose values increased. Therefore, the analysis of variance of the regression established a linear model of the second degree. The rate of degradation " $\mathrm{C}$ " of the ADF in the rumen is slow $(3.13 \% / \mathrm{h}$, on average), which is related to the structural characteristics of the lignocelluloses fraction. This has practical implications as the degree of the digestion of the ADF is highly dependent on the time of permanence of the food in the rumen or its speed of passage. Like the DENDF, the DEADFs show minimum reductions of: 68.28 to $53.70 \%, 57.39$ to $46.99 \%$ and 63.63 to $54.07 \%$, respectively, for the ages of 130, 150 and 170 cut days, when the pass rates go from 2 to $8 \% 7 \mathrm{~h}$. Results that indicate that the degradability and energy value of the lignocelluloses fraction are reduced in the order of 14.58, 10.40 and 9.56 percentage points for animals of high level of production and consumption, where the digestive transit is fast. ${ }^{13}$ Regarding the $\operatorname{DPADF}(\mathrm{a}+\mathrm{b})$, the barley at 130 and 170 cut days suffered the greatest influence of $\mathrm{k}=8 \% / \mathrm{h}$, corresponding $37.85 \%$ and $38 \%$ of the degradation decrease compared to the barley of 150 days of cutting $(33.19 \%)$ and, associated with the potentially " $b$ " fractions $(44.98 \%$ and $43.37 \%)$ and degradation rates "a" (3.01 and 3.35\%/h) the barley at 130 and 170 days of cutting required more time in the rumen to be degraded the lignocelluloses fraction.

Table 6 Means and regression equations of the degradability parameters of the acid detergent fiber of barley at different cut ages

\begin{tabular}{|c|c|c|c|c|}
\hline \multirow[t]{2}{*}{ Parameters of degradation } & \multicolumn{3}{|c|}{ Cutting ages (days) } & \multirow[t]{2}{*}{ Regression equations and coefficients of determination (\%) } \\
\hline & 130 & 150 & 170 & \\
\hline a (\%) & $41.44^{\mathrm{a}}$ & $38.23^{b}$ & $37.40^{c}$ & $Y=\mid 20.5829-0.9972 * * E+0.0030 * * E^{2}\left(R^{2}=60.20\right)$ \\
\hline b (\%) & $44.98^{\mathrm{a}}$ & $32.02^{\mathrm{b}}$ & $43.37^{\mathrm{a}}$ & $\mathrm{Y}=721.5887-9.154 * * * \mathrm{E}+0.0303 * * * \mathrm{E}^{2}\left(\mathrm{R}^{2}=67.40\right)$ \\
\hline$c(\% / h)$ & $3.0 \mathrm{I}^{\mathrm{a}}$ & $3.02^{\mathrm{a}}$ & $3.35^{\mathrm{a}}$ & $Y=11.1167-0.1165^{\text {ns }} E+0.00042^{\text {ns }} E^{2}\left(R^{2}=5.00\right)$ \\
\hline DPADF (\%) & $86.4 I^{\mathrm{a}}$ & $70.33^{c}$ & $80.76^{\mathrm{b}}$ & $\mathrm{Y}=837.0|| \mathrm{I}-10.08 \mid * * * \mathrm{E}+0.033 * * * \mathrm{E}^{2}\left(\mathrm{R}^{2}=65.84\right)$ \\
\hline DEADF $2 \% / h$ & $68.28^{\mathrm{a}}$ & $57.39^{c}$ & $63.63^{b}$ & $\mathrm{Y}=556.8742-6.543 * * * \mathrm{E}+0.0214 * * * \mathrm{E}^{2}\left(\mathrm{R}^{2}=8 \mathrm{I} .52\right)$ \\
\hline DEADF $5 \% / h$ & $58.26^{\mathrm{a}}$ & $50.23^{c}$ & $54.07^{\mathrm{b}}$ & $\mathrm{Y}=399.4 \mid 46-4.55 \mathrm{I} * * * \mathrm{E}+0.0 \mathrm{I} 48 * * * \mathrm{E}^{2}\left(\mathrm{R}^{2}=80039\right.$ \\
\hline DEADF $8 \% / h$ & $53.70^{\mathrm{a}}$ & $46.99^{c}$ & $49.65^{b}$ & $Y=325.6275-3.6138 * * * E+0.0117 * * * E^{2}\left(R^{2}=78.79\right)$ \\
\hline
\end{tabular}

Means with the same letter within a row do not differ significantly from each other, by the Turkey test at $5 \%$ probability.

a, soluble fraction (initial degradability); b, potentially degradable fraction (maximum degradability); c, rate of degradation of fraction b; DPADF, maximum potential degradability of the acid detergent fiber; DEADF $2 \% / \mathrm{h}$, effective ruminal degradability of the acid detergent fiber with passage rate of $2 \% /$ hour; DEADF $5 \% / \mathrm{h}$, effective ruminal degradability of the acid detergent fiber with passage rate of $5 \% /$ hour; DEADF $8 \% / \mathrm{h}$, effective ruminal degradability of the acid detergent fiber with passage rate of $8 \% /$ hour of barley at different cutting ages. $* ; * ; * *$ Significant when $\mathrm{P}<0.05, \mathrm{P}<0.0 \mathrm{I}$ and $\mathrm{P}<0.00 \mathrm{I}$, respectively. 


\section{Discussion}

According to Table 2 the results are partially in agreement with that reported by Slanac et al. ${ }^{15}$ who refer to the decrease in DM disappearance as the age of the plant increases, a response due to lignifications of the fiber. The values of the soluble fraction " $a$ " were relatively low for the MS, whose mean was $18.00 \%$. This value is lower than that found by Cordero FA, ${ }^{15}$ who observed $24.58 \%$. This fraction "b" that is potentially degradable by the microorganisms of the rumen and that may be related to the high levels of NDF and ADF of the species under study, allowed the decrease of the forage degradability ${ }^{16}$ and consequently a decrease in the speed or rate of degradation "c" of the MS, whose means fluctuated between $1.67 \% / \mathrm{h}$ and $2.33 \% / \mathrm{h}$. These figures (slow degradation) indicate that the amount of energy that can be extracted from the barley during the time it remains in the rumen is low. ${ }^{16}$ The low degradation rates gave rise to relatively low DEDM at the passage rates of $2 \% / \mathrm{h}, 5 \% / \mathrm{h}$ and $8 \% / \mathrm{h}$. The DEMS observed for the three cutting ages are lower than that found by Cordero FA ${ }^{15}$ whose DEDM varied between $70.48 \%$ and $54.23 \%$, with the same passages rates of the forage and with degradation rate "c" of $8.51 \% / \mathrm{h}$. Fact, which is probably due to the differences in the content of the cell walls, together with the lignifications of the cell wall, factors that become severe limitations for the improvement of the ruminal digestion of the nutrients contained in the forages that adversely affect DM degradability. ${ }^{17}$ Considering that fibrous carbohydrates $(\mathrm{FC}=\mathrm{NDF})$ constitute the main components of forages, in the present study the rate of degradation "c" of NDF (cell wall, palisade cell epidermis), ${ }^{18}$ in addition of being of slow degradation in the rumen, it was observed that at the ages of 130 and 150 days there were no significant differences $(\mathrm{P}>0.05)(2.80 \% / \mathrm{h}$ vs $2.77 \% / \mathrm{h})$, deferring these with the highest rate of degradation $(3.39 \% / \mathrm{h})$ obtained after 170 days of cutting. As expected, the DPADF $(80.76 \%)$ at the age of 170 days should be lower than the DPADF $(70.33 \%)$ observed at 150 days of cut, since the degradation decrease occurs as the age of the product increases. The plant, response due to lignifications of the fiber, ${ }^{10}$ although the nutritional quality does not change drastically with the maturity of the plant. ${ }^{14}$ Fact that could be due in the present experiment to the interaction between the cut age and the ruminal incubation time (Table 1). In the constant rate of degradation "c" of the ADF, no significant differences were observed $(\mathrm{P}>0.05)$ between cutting ages, whose average was $3.13 \% / \mathrm{h}$.

\section{Conclusion}

i. In the three ages of barley cut the degradability's (disappearance) of dry matter, crude protein, neutral detergent fiber and acid detergent fiber increased according to the ruminal incubation time. The decrease in the disappearance of dry matter occurred from 130 to 150 days of barley cut.

ii. The ruminal degradation potential of the dry matter did not vary with the age of cut, the non-degradable fraction oscillating between $9.73 \%$ and $17.17 \%$. The effective degradability's of the dry matter did not vary with the age of cut in the rates of established passages.

iii. The degradation rate of the protein was less than 130 days compared to that estimated for 150 and 170 days of cutting.

iv. Due to the high effective degradability of the crude protein in the three cutting ages, it is possible to classify barley as a species of high nutritional quality.

v. The rapidly degradable "a" and slowly degradable "b" fraction of the NDF showed values similar to the 130,150 and 170 cut days, causing high potential degradability's and in degradability's in the order of $14.79 \%, 27.19 \%$ and $18.82 \%$. vi. Due to the effective degradability of the neutral and acid detergent fiber at the passage rates of $2 \%$ and $5 \%$ / hour, barley at the age of 130 days of growth allows it to be classified as forage with a good nutritional potential for ruminants.

\section{Funding details}

The FOCAM funds allowed carrying out this study through the Vice-Rector of the National University of Huancavelica-Peru.

\section{Acknowledgments}

This study was supported with FOCAM funds from the Project "Evaluation of the sowing of oats and barley associated with tare and conserve the forage for the feeding of alpacas in the high Andean zones in the district, province and Huancavelica region of the National University of Huancavelica and the human team that make up the Laboratory of animal nutrition and food evaluation.

\section{Conflicts of interest}

The author declares that there are no conflicts of interest.

\section{References}

1. Villanueva J, San Martín F. Feeding Heifers in Growth Based on Harvest Residues Treated with Urea and Supplemented with Surplus Protein, at the National University of San Marcos. Rev de Investigaciones Pecuarias. 1997;8(1):39-48.

2. Nocek J. In situ and other methods to estimate ruminal protein and energy digestibility: a review. Journal of Dairy Science. 1988;71(8):2051-2069.

3. Silva DJ, Queiroz AC. Food analysis: chemical and biological methods. $3^{\text {rd }}$ Edition. 2002.

4. Ayala Burgos AJ, Rosado Rivas CM, Capetillo Leal CM, et al. Evaluation of the bag washing method (manual and washing machine) in the technique of ruminal degradation in situ. Livestock Technique in Mexico. 2003;41(3):337-342.

5. Yescas R, Bárcena Gama R, Mendoza Martínez GD, et al. Digestibility in situ of diets with stubble of corn or oat straw with fibrolytic enzymes. Agrociencia. 2004;38(1):23-31.

6. Orskov ER, McDonald I. The estimation of protein degradability in the rumen from incubation measurements weighted according to rate of passage. The Journal of Agricultural Science. 1979;92(2):499-503.

7. AFRC. Energy and protein requirements of ruminants. CAB International.1993.

8. SAS. Statiscal Analisys System. SAS/STAT: user's Guide: Statistics. Release 9.2. 2009.

9. Villela V, Maldonado VH, Coelho da Silva JF. Chemical-Bromatological Composition and in situ degradability of dry matter, crude protein and neutral detergent fiber cascates the fruit of three varieties of passion fruit (Passiflora spp). Rev Bras Zoot. 1999;28(5):1148-1158.

10. Rogério da Silva, Maldonado VH, Coelho da Silva JF. Degradability in situ of dry matter, crude protein and neutral detergent fiber do capimfurach ão (Panicum repens L.) submetered adubação e em different cutting units. Rev Bras Zoot. 1999;28(4):799-807.

11. NRC. Nutrient requirements of small ruminants: sheep, goats, cervids and new world camelids. National Academic Press. 2007.

12. Klopfenstein TJ, Mass RA, Creighton KW, et al. Estimating forage protein degradation in the rumen. J Ani Sci Anim Sci. 2001;79:208-217.

13. Salado EE, Eat rum EA, Silva C, et al. Soybean husk and wheat afrechillo: kinetics of the rumen degradability of the fiber. XIX Meeting 
of the Latin American Association of Animal Production. 2005:24-28.

14. Slanac AL, Balbuena O, Rochinotti D, et al. Ruminal degradation of the dry matter of two species of the natural pastureland of the Argentine northeast. Scientific and Technological Communications. 2006.

15. Cordero FA, Contreras PJL, Curasma CJ, et al. Degradability in situ and estimation of the consumption of forages and concentrates in alpacas (Vicugna pacos). Rev Inv Vet Peru. 2018;29(2):429-437.

16. Razz R, Clavero T, Urdaneta J, et al. Nitrogenous fractions of two ecotypes of Leucaena leucocephala under different levels of fertilization. Rev Past and For. 1999;22:65-70.

17. $\mathrm{Ku}$ Vera JC, Ramírez L, Jiménez G, et al. Trees and shrubs for production animal in the Mexican tropics. IV International Seminar on Sustainable Agricultural Systems. Center for Research in Sustainable Production Systems Farming Cali. Colombia. 1999.

18. Granet E, Barry P. Microscopic study of plant wall digestion of soybean and colza rumen teguments. Reprod Nutr Develop. 1987;27(1B):246-248. 